\title{
COMPARISON OF NATURAL AND SYNTHETIC MATERIALS TO IMPROVE HEARING AFTER OBLITERATION OF THE MASTOID CAVITY
}

\author{
Abdelrahman E. M. Ezzat ${ }^{1}$, Marwa M. El-Begermy², Ahmed M. A. Mahmoud³, \\ Mustafa I. Eid ${ }^{1}$ \\ ${ }^{1}$ ENT Department, Faculty of Medicine, Al-Azhar University Hospital, Cairo, Egypt \\ ${ }^{2}$ ENT Department, Faculty of Medicine, Ain-Shams University, Cairo, Egypt \\ ${ }^{3}$ Audiology Unit, ENT Department, Faculty of Medicine, Al-Azhar University Hospital, Cairo, Egypt
}

Corresponding author: Marwa M. El-Begermy, ENT Department, Faculty of Medicine, Ain-Shams University, Cairo, Egypt, tel.: +201111766566, e-mail: marwabegermy@gmail.com

\begin{abstract}
Background: Indications for removal of mastoid air cells and obliterating the mastoid cavity vary considerably from surgeon to surgeon. Various obliteration techniques have been recommended to eliminate open cavity problems. Here we investigated the difference between natural and synthetic filling materials to improve hearing after obliteration of the mastoid cavity.
\end{abstract}

Setting: Academic tertiary care medical centers (Al-Azhar and Ain-Shams University Hospitals).

Study design: Retrospective comparative study included 60 patients divided into 2 equal groups.

Methods: The study was conducted over 6 years from 2008-14. The mean follow-up time was 3.5 years.

Results: We found that serviceable hearing $(\leq 30 \mathrm{~dB})$ was obtained after surgery in 52 patients $(86.6 \%)$. In cases where natural materials were used in reconstruction, the average gain in $\mathrm{AC}$ was $25.5 \mathrm{~dB}$ and in $\mathrm{BC}$ it was $1.1 \mathrm{~dB}$, while in cases where synthetic materials were used the average gain in $\mathrm{AC}$ was $26 \mathrm{~dB}$ and in $\mathrm{BC}$ it was $0.5 \mathrm{~dB}$. There was significant improvement in the mean postoperative AC compared to the mean preoperative AC. However, there was no statistically significant difference between the use of natural and synthetic materials in improving postoperative hearing.

Conclusions: Both natural and synthetic materials help in improvement of hearing after obliteration of the mastoid cavity. There is no statistically significant difference between the materials.

Keywords: hearing gain $\bullet$ mastoid cavity • obliterated mastoid

\section{ESTUDIO COMPARATIVO ENTRE LOS MATERIALES NATURALES Y SINTÉTICOS EN LA MEJORA DE LA AUDICIÓN TRAS LA OBLITERACIÓN DE LA CAVIDAD MASTOIDEA}

\section{Resumen}

Introducción: Los cirujanos difieren en las opiniones sobre la necesidad de eliminar las células mastoideas y de la obliteración de la cavidad mastoidea. Se recomienda una variedad de técnicas de la obliteración con el objetivo de eliminar los problemas de la cavidad abierta. Hemos analizado la diferencia entre los materiales naturales y sintéticos de relleno desde el punto de vista de la mejora auditiva tras la obliteración de la cavidad auditiva.

La prueba se realizó en el centro médico académico especializado (Al-Azhar and Ain-Shams University Hospitals).

Plan de estudio: Ha sido un estudio comparativo retrospectivo, realizado en 60 pacientes divididos en dos grupos iguales.

Métodos: El estudio se estaba realizando durante seis años (2008-2014). La media de seguimiento fue de 3 años y medio.

Resultados: El estudio demostró, que como resultado de la intervención cirúgica se consiguió una audición correcta (umbral de $30 \mathrm{~dB}$ o inferior) en 52 pacientes (un 87\%). En los casos de aplicación del material natural para la reconstrucción, el beneficio de la conducción aérea fue de $25,5 \mathrm{~dB}$, y de la conducción ósea $1,1 \mathrm{~dB}$. En los casos de utilización del material sintético para la reconstrucción, los valores que se comparan fueron, respectivamente, $26 \mathrm{~dB}$ y 0,5 dB. En consecuencia, teniendo en 
cuenta la tasa media, hubo una mejora significativa en la conducción aérea después de la cirugía, en comparación con el estado previo a la intervención. No se han observado diferencias estadísticamente significativas entre el impacto de los materiales naturales y sintéticos en el resultado de la conducción aérea y ósea.

Conclusiones: Ambos materiales, naturales y sintéticos, contribuyen a mejorar la audición tras la obliteración de la cavidad mastoidea. No hay diferencias estadísticamente significativas entre ambos tipos de material.

Palabras clave: mejoras auditivas • cavidad mastoidea • obliteración del apófisis mastoides

\section{СРАВНЕНИЕ ВЛИЯНИЯ НАТУРАЛЬНЫХ И СИНТЕТИЧЕСКИХ МАТЕРИАЛОВ НА УЛУЧШЕНИЕ СЛУХА ПОСЛЕ ОБЛИТЕРАЦИИ СОСЦЕВИДНОГО ОТРОСТКА}

\section{Изложение}

Введение: Хирурги по-разному относятся к показаниям к удалению ячеек сосцевидного отростка и облитерации мастоидальной полости. Существует множество различных методов облитерации для устранения проблем открытой полости. Мы провели анализ различия между натуральными и синтетичными заполнителями в плане их воздействия на улучшение слуха после облитерации сосцевидного отростка.

Место проведения исследования - специальный академический медицинский центр (Al-Azhar and Ain-Shams University Hospitals).

План исследования: Было проведено ретроспективное сравнительное исследование, в котором приняло участие 60 больных, разделенных на две равных группы.

Методы: Исследование проводилось на протяжении 6 лет (2008-2014). Среднее время наблюдения составило 3,5 года.

Результаты: Исследование показало, что в результате хирургической процедуры было достигнуто улучшение слуха (порог 30 дБ или меньше) у 52 больных (87\%). В случаях использования натурального материала для реконструкции среднее улучшение воздушной проводимости составило 25,5 дБ, а костной проводимости 1,1 дБ. В случаях применения синтетического материала для реконструкции сравниваемые значения составили, соответственно, 26 дБ и 0,5 дБ. В связи с тем, учитывая средний показатель, было отмечено значительное улучшение воздушной проводимости после операции по сравнению с состоянием до операции. Не было отмечено статистически значимых различий между влиянием натуральных и синтетических материалов на результат воздушной и костной проводимости.

Выводы: Как натуральные, так и синтетические материалы оказывают влияние на улучшение слуха после облитерации сосцевидного отростка. Нет статистически значимых различий между этими материалами.

Ключевые слова: улучшение слуха • сосцевидная пещера • облитерация сосцевидного отростка

\section{PORÓWNANIE MATERIAŁÓW NATURALNYCH I SYNTETYCZNYCH W KONTEKŚCIE POPRAWY SŁUCHU PO OBLITERACJI JAMY SUTKOWEJ}

\section{Streszczenie}

Wstęp: Chirurdzy w różny sposób postrzegają wskazania do usunięcia komórek sutkowych oraz obliteracji jamy sutkowej. Zaleca się wiele różnych technik obliteracji w celu usunięcia problemów otwartej jamy. Zanalizowaliśmy różnicę pomiędzy naturalnymi i syntetycznymi materiałami wypełniającymi w kontekście poprawy słuchu po obliteracji jamy słuchowej.

Miejsce: Specjalistyczne akademickie centrum medyczne (Al-Azhar and Ain-Shams University Hospitals).

Plan badania: Było to porównawcze badanie retrospektywne przeprowadzone wśród 60 pacjentów podzielonych na dwie równe grupy.

Metody: Badanie było prowadzone przez ponad sześć lat (2008-2014). Średni czas obserwacji wynosił 3,5 roku. 
Wyniki: Badanie wykazało, że w wyniku zabiegu chirurgicznego uzyskano poprawny słuch (próg $30 \mathrm{~dB}$ lub mniej) u 52 pacjentów (87\%). W przypadkach wykorzystania naturalnego materiału do rekonstrukcji, średni zysk przewodnictwa powietrznego wnosił 25,5 dB, a przewodnictwa kostnego $1,1 \mathrm{~dB}$. W przypadkach wykorzystania syntetycznego materiału do rekonstrukcji, porównywane wartości wyniosły odpowiednio $26 \mathrm{~dB}$ i $0,5 \mathrm{~dB}$. W związku z powyższym, biorąc pod uwagę średni wskaźnik, pojawiła się znaczna poprawa przewodnictwa powietrznego po operacji w porównaniu ze stanem przed operacją. Nie było statystycznie znaczących różnic pomiędzy wpływam materiałów naturalnych i syntetycznych na wynik przewodnictwa powietrznego i kostnego.

Wnioski: Zarówno materiały naturalne jak i syntetyczne mają wpływ na poprawę słuchu po obliteracji jamy sutkowej. Nie ma statystycznie znaczącej różnicy pomiędzy tymi materiałami.

Słowa kluczowe: zyski słuchowe • jama sutkowa • obliteracja wyrostka sutkowego

\section{Background}

Indications for removal of mastoid air cells and obliterating the mastoid cavity varies considerably from surgeon to surgeon [1]. Various obliteration techniques have been recommended to eliminate open cavity problems. Mosher in 1911 was the first to use the soft tissue flap technique in which a post-aural subcutaneous flap is used to fill the cavity after the mastoid has been obliterated. Subsequently, soft tissue flaps, free bone, cartilage grafts, autograft, and synthetic fillers have been used to reduce mastoid cavities and reconstruct the canal wall [2].

In principle, any surgical procedure on the ear can affect its acoustic function, including surgery of the external ear [3]. The volume of the ear canal and the width of its entrance affect sound resonance [4]. In this study, we aimed to find out the difference in hearing improvement between cases of mastoid obliteration without ossicular reconstruction in which natural and synthetic materials were used as fillers.

\section{Material and methods}

Exactly 60 patients underwent obliteration of the mastoid cavity, 30 in which natural materials were used to fill the cavity and 30 in which synthetic materials were used. The study was conducted at academic tertiary-care medical centers (Al-Azhar and Ain-Shams University Hospitals) for more than 6 years (between 2008 and 2014). The mean follow-up time was 3.5 years.
The 60 patients were either primary (obliteration was done in the same site) or secondary (cavity opened after a previous operation). The research aimed to compare the use of natural and synthetic materials in overcoming postoperative cavity problems. Patients with previous sensorineural hearing loss were excluded from the study. Informed consent was obtained from the patients or their legal representatives. In terms of patient epidemiology, there was no statistically significant difference between the two groups regarding mean age, gender, or geographic origin as shown in Table 1 . The mean age was $29.6 \pm 15.4$ $\mathrm{SD}$ in the natural material group and $26.5 \pm 12.4 \mathrm{SD}$ in the synthetic material group.

\section{Surgical technique}

Multiple techniques (atticotomy, atticoantrotomy, or canal wall down) were used in this study as described by Meyer et al. [5]. There was no statistically significant difference between the types of operative techniques $\left(\chi^{2}=2.06\right.$, $p=0.35$ ), as summarized in Table 2 .

Tragal cartilage was used in all cases to reconstruct the tympanic membrane (TM) as it was better in resisting infection. The graft was applied to the stapes head if it was present or to the promontory if stapes supra-structure was absent (ossiculoplasty was postponed to a second stage). Additionally, functional reconstruction of the mastoid cavity was performed. Several materials were randomly used, including both natural and synthetic materials.

Table 1. Descriptive statistics of residency, age, and gender of patients

\begin{tabular}{lccc}
\hline \multicolumn{1}{c}{ Demographic data } & $\begin{array}{c}\text { Natural material } \\
\boldsymbol{n}(\%)\end{array}$ & $\begin{array}{c}\text { Synthetic material } \\
\boldsymbol{n}(\%)\end{array}$ & $p$-value \\
\hline Residency, $\mathbf{n}(\%)$ & $20(66.7)$ & $18(60)$ & $0.7^{*}$ \\
\hline Rural & $10(33.3)$ & $12(40)$ & $0.82^{*}$ \\
\hline Urban & & $26.5 \pm 12.4$ & $0.56^{*}$ \\
\hline Age (years) & $29.6 \pm 15.4$ & & $11(36.6)$ \\
\hline Mean \pm SD & & $19(63.4)$ & \\
\hline Male & $9(30)$ & & \\
\hline Female & $21(70)$ & & \\
\hline
\end{tabular}

* Not significant at $p \geq 0.05$ 
Table 2. Types of operation used

\begin{tabular}{lccccc}
\hline & \multicolumn{5}{c}{ Type of surgery } \\
\cline { 2 - 5 } & A \&A & Primary & MW & $\begin{array}{c}\text { Secondary } \\
\text { (open cavity) }\end{array}$ & $p$-value \\
\cline { 2 - 5 } & 18 & 15 & 14 & $\mathbf{R}$ \\
\hline No. of patients, $\mathrm{n}$ & $30 \%$ & $25 \%$ & $23.4 \%$ & 13 & $0.35^{*}$ \\
\hline Percentage (\%) & & MRM & $21.6 \%$ & \\
\hline
\end{tabular}

$A \& A$ - atticotomy and atticoantrotomy; CWW - canal wall window mastoidectomy; MRM - modified radical mastoidectomy; $R$ - reconstruction only. ${ }^{*}$ not significant at $p \geq 0.05$

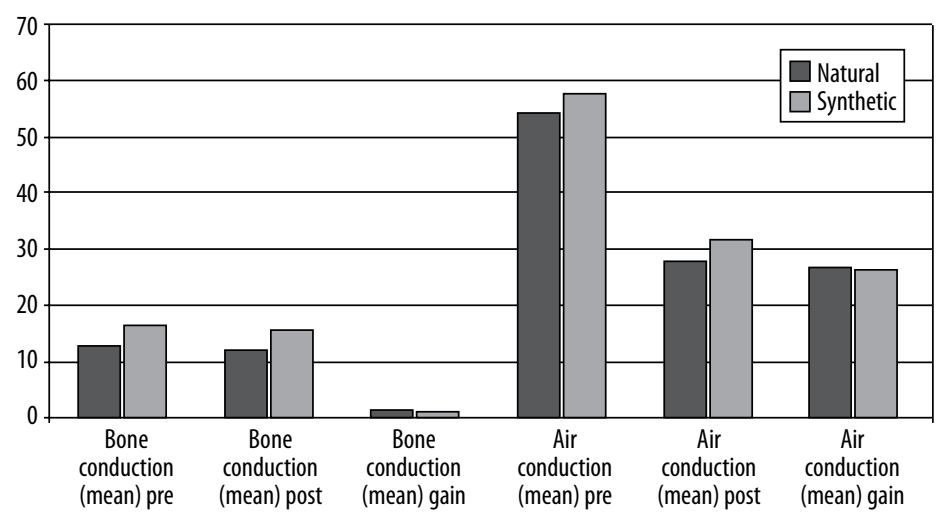

Figure 1. Hearing by bone and air conduction of the natural and synthetic groups for both the preoperative (pre) and postoperative (post) periods

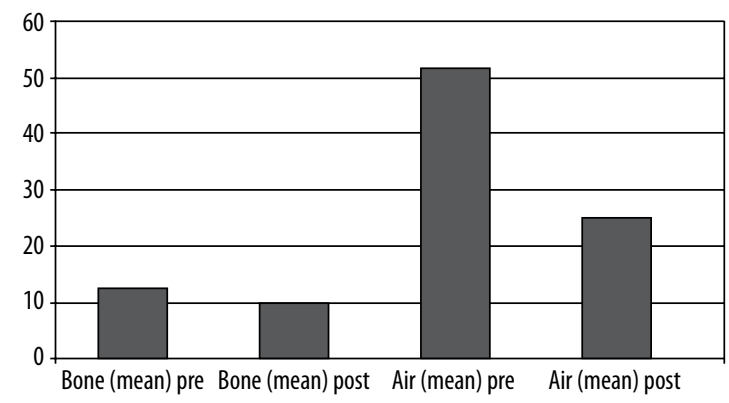

autologous cartilage was used in large cavities if other materials were lacking according to Eavey and Lubianca [9].

The synthetic materials were as follows. 1) Titanium mesh as described by Wilson and David [10]. The mesh was bent by manual manipulation and cut using special wire scissors. The required size was cut and placed slightly anterior to the facial ridge, reaching in depth the bony tympanic annulus. The composite titanium mesh was then attached to the remaining parts of the adjacent superior and inferior cortical bone and secured with two 3-mm titanium screws. 2) Bioglass as described by Ezzat and Eid [11]. The bioglass was mixed with blood and filled the mastoid cavity, sparing the epitympanum which was not obliterated. Temporalis fascia graft was placed on the bioglass.

Mean hearing by bone conduction and air duction of all patients for both the preoperative (pre) and postoperative (post) periods

The natural materials used were as follows. 1) Inferiorly pedicled musculo-periosteal flap alone according to Chole et al. [6]. The flap was fashioned from the previously prepared, posteriorly based musculo-periosteal flap with attention to preserve its blood supply from the posterior auricular artery. 2) Composite multi-fractured osteo-periosteal flap according to Uçar [7]. The upper margin of inferiorly based flap was incised; the periosteum was downwards elevated with a 7-mm chisel, rising with it thin bone lamellae 1-mm thick. The composite flap was then used for obliteration. 3) Obliteration of the mastoid by inferiorly pedicled musculoperiosteal flap with cartilage according to Sudhoff and Hildmann [8]. 4) Soft tissue grafts including connective tissue harvested from the postauricular region, larger free fascia grafts, free muscle graft and Palva flap (anteriorly pedicled periosteal flap). 5) Finally,

\section{Audiological assessment}

Pure tone audiometry was performed before surgery, and 3,6 , and 12 months (and sometimes 2 years) postoperatively. Hearing evaluation was done using two methods. 1) Comparing the means of postoperative gain in air conduction $(\mathrm{AC})$ and bone conduction $(\mathrm{BC})$ and the gain = difference between pre- and postoperative levels. 2) Calculating the percentage of the patients having postoperative serviceable hearing ( $\mathrm{AC} \leq 30 \mathrm{~dB}$ ). Patients with preoperative sensorineural hearing loss were excluded from the study.

\section{Statistical analyses}

Statistical analysis was performed by a specialized company using the statistical software package SPSS for Windows, version 20 (SPSS, Inc. Chicago, IL). A chi-square 
Table 3. Mean hearing level in cases of using natural and synthetic materials in reconstruction or obliteration

\begin{tabular}{|c|c|c|c|c|}
\hline & \multicolumn{2}{|c|}{ Material } & \multirow{2}{*}{\multicolumn{2}{|c|}{$t$-test }} \\
\hline & Natural material & Synthetic material & & \\
\hline & Mean \pm SD & Mean \pm SD & $t$ & $p$-value \\
\hline Bone conduction (mean) pre & $12.581 \pm 10.830$ & $16.250 \pm 12.575$ & -0.741 & $0.463^{*}$ \\
\hline Bone conduction (mean) post & $11.573 \pm 10.175$ & $15.417 \pm 11.664$ & -0.829 & $0.413^{*}$ \\
\hline Bone conduction (mean) gain & $1.008 \pm 2.610$ & $0.833 \pm 1.291$ & 0.159 & $0.875^{\star}$ \\
\hline Air conduction (mean) pre & $53.935 \pm 10.614$ & $57.167 \pm 17.198$ & -0.615 & $0.543^{*}$ \\
\hline Air conduction (mean) post & $27.323 \pm 7.268$ & $31.167 \pm 10.028$ & -1.116 & $0.272^{*}$ \\
\hline Air conduction (mean) gain & $26.613 \pm 5.841$ & $26.000 \pm 8.764$ & 0.217 & $0.830^{*}$ \\
\hline
\end{tabular}

SD - standard deviation; * not significant at $p \geq 0.05$; ${ }^{* *}$ significant at $p \leq 0.05$; pre - preoperative; post - postoperative

Table 4. Descriptive statistics for hearing evaluation in both bone and air conduction of all patients

\begin{tabular}{|c|c|c|c|c|c|c|}
\hline & \multicolumn{2}{|c|}{ Bone conduction } & \multicolumn{2}{|c|}{ Paired differences } & \multicolumn{2}{|c|}{ Paired samples test } \\
\hline & Range & Mean \pm SD & Mean & SD & $t$ & $p$-value \\
\hline Bone conduction (mean) pre & $2.5-35.0$ & $13.176 \pm 11.026$ & \multirow{2}{*}{0.980} & \multirow{2}{*}{2.432} & \multirow{2}{*}{2.450} & \multirow{2}{*}{$0.190^{*}$} \\
\hline \multirow[t]{3}{*}{ Bone conduction (mean) post } & $3.75-33.75$ & $12.196 \pm 10.356$ & & & & \\
\hline & \multicolumn{2}{|c|}{ Air conduction } & \multicolumn{2}{|c|}{ Paired differences } & \multicolumn{2}{|c|}{ Paired samples test } \\
\hline & Range & Mean \pm SD & Mean & SD & $t$ & $p$-value \\
\hline Air conduction (mean) pre & $34.0-85.0$ & $54.459 \pm 11.680$ & \multirow{2}{*}{26.514} & \multirow{2}{*}{6.257} & \multirow{2}{*}{25.777} & \multirow{2}{*}{$0.000^{\star \star}$} \\
\hline Air conduction (mean) post & $14.0-48.0$ & $27.946 \pm 7.749$ & & & & \\
\hline
\end{tabular}

SD - standard deviation; * not significant at $p \geq 0.05$; ${ }^{\star \star}$ significant at $p \leq 0.05$; pre - preoperative; post - postoperative

test and a paired-samples test were used to compare the groups. The significance level was set at $p \leq 0.05$.

\section{Results}

This was a retrospective comparative study of the two groups of patients. Comparative parameters and results are summarized in Tables 3 and 4 . Pre- and postoperative hearing assessment of the natural material group revealed that the average $\mathrm{AC}$ gain was $25.5 \mathrm{~dB}$ and $\mathrm{BC}$ gain was $1.1 \mathrm{~dB}$. Serviceable hearing (threshold $\leq 30 \mathrm{~dB}$ ) was obtained in 25 of 30 patients (83.4\%). In the synthetic material group, pre- and postoperative hearing assessment showed that the average $\mathrm{AC}$ gain was $26 \mathrm{~dB}$ and in $\mathrm{BC}$ it was $0.5 \mathrm{~dB}$. Serviceable hearing (threshold $\leq 30 \mathrm{~dB}$ ) was obtained in 27 of 30 patients (90\%) as shown in Figure 1.

Statistical analysis showed there was no significant change in BC before and after the operation $(t=2.45, p=0.19)$. In addition, by paired samples test there was significant improvement of AC after the operation $(t=25.7, p \leq 0.05)$ as shown in Table 4 and Figure 2. However, there was no significant difference $(p \geq 0.05)$ between natural and synthetic materials as regards the mean pre- and post-operative AC and $\mathrm{BC}$, as shown in Table 3 and Figure 1.

\section{Discussion}

Over the past years, surgical procedures in chronic otitis media with cholesteatoma have changed significantly. The primary goal of the canal wall reconstruction is the creation of a dry, safe ear. Hearing gain is a secondary, although important consideration. Hearing gain can be achieved by obliteration of the open mastoid cavity as well as by ossicular construction. An additional advantage is that hearing aids are easier to fit into an obliterated cavity than into an open cavity. The obliterated cavity is also more likely to retain its epithelial migratory potential and be self-cleaning [12].

In our study, we found that serviceable hearing $(\leq 30 \mathrm{~dB})$ was obtained after surgery in 52 patients $(86.6 \%)$, while there was no worsening of the air-bone gap in the follow-up period. Additionally, high-frequency sensorineural hearing loss was detected in 4 patients $(6.6 \%)$, probably caused by acoustic trauma during drilling. Berrettini et al. [13] reported functional features in obliteration of the mastoid with a temporo-parietal fascia and found improved hearing in $91 \%$ of cases. After 5 years, 3 patients had significant worsening of the air-bone gap $(>10 \mathrm{~dB})$, and marked tympanic retraction was observed in 2 of them; high-frequency sensorineural hearing loss, probably caused by acoustic trauma during drilling, was detected in 4 patients (9\%). However, Della Santina and Lee [14] found 
that there was no significant change in the PTA for a long time after using Ceravital (a synthetic ceramic material).

Visvanathan et al. [15] reported hearing thresholds $\leq 30$ $\mathrm{dB}$ in 53 patients, $\leq 50 \mathrm{~dB}$ in 31 patients, and $\leq 70 \mathrm{~dB}$ in 15 patients. The mean improvement of the air-bone gap was $24.8 \mathrm{~dB}$. Della Santina and Lee [14] reported that the postoperative hearing improvement with Ceravital reconstruction after an average of 7 years (range up to 17.8 years) was $43.9 \pm 20.5 \mathrm{~dB}$ in the mean $\mathrm{AC}$ and $16.8 \pm 13.8 \mathrm{~dB}$ in $\mathrm{BC}$, with an air-bone gap of $27.1 \pm 11 \mathrm{~dB}$.

In our study the mean pre- and postoperative air-bone gaps for all patients were 54.4 and $27.9 \mathrm{~dB}$, respectively, giving a mean improvement of $26 \mathrm{~dB}$ irrespective of the material used in obliteration or the type of surgery.

Hearing improvement after cavity obliteration may be explained by improvement of sound resonance in the ear canal. The volume of the ear canal and the width of the canal inlet are important factors in sound conduction which affect the resonance of the canal. A resonance induced amplification of sound pressure reaches up to $20 \mathrm{~dB}$ in the normal ear canal at frequencies of $1000-3000 \mathrm{~Hz}$. The wavelengths of these frequencies are about four times the canal length [4].

Furthermore, the short period of study did not give us more information about long-term outcomes; we therefore recommend longer follow-up times.

\section{Conclusions}

Both natural and synthetic materials can help in hearing gain after obliteration of the mastoid cavity. There is no significant difference between them. However, natural materials are preferred in terms of cost-effectiveness.

\section{Acknowledgement}

We acknowledge Prof. Sahar I. Yassin, Professor of Public Health, Faculty of Medicine, Cairo University, Egypt, for her help with statistical work.

\section{References:}

1. Lambert P. Mastoidectomy. In: Cumming $\mathrm{C}$ et al. (eds). Otolaryngology: Head and NeckSurgery. 4th ed. New York: Mosby Inc., $2005 ; 3075-87$.

2. Uçar C. External auditory canal reconstruction and mastoid cavity obliteration with composite multifractured osteoperiosteal flap: a preliminary study. Turk J ENT (Kulak Burun Bogaz Ihtis Derg), 2006; 16(3): 127-31.

3. Hüttenbrink K. Biomechanical aspects of middle ear reconstruction. In: Jahnke K (ed.), Middle Ear Surgery: Recent advances and future directions. New York: Thieme, 2004; 24-52.

4. Dornhoffer JL. Hearing results with cartilage tympanoplasty. Laryngoscope, 1997; 107(8): 1094-9.

5. Meyer T, Strunk J, Lambert P. Cholesteatoma. In: Bailey BJ et al. (eds). Head and Neck Surgery: Otolaryngology. $4^{\text {th }}$ ed. Philadelphia: Lippincott Williams \& Wilkins, 2006; 2020-100.

6. Chole R, Brodie H, Jacob A. Surgery of the mastoid and petrosa. In: Bailey BJ et al. (eds). Head and Neck Surgery: Otolaryngology. $4^{\text {th }}$ ed. Philadelphia: Lippincott Williams \& Wilkins, 2006; 2094-111.

7. Uçar C. Canal wall reconstruction and mastoid obliteration with composite multi-fractured osteoperiosteal flap. Eur Arch Otorhinolaryngol, 2006; 263(12): 1082-6.
8. Sudhoff H, Hildmann H. Cholesteatoma surgery. In: Hildmann $\mathrm{H}$ and Sudhoff $\mathrm{H}$ (eds), Middle Ear Surgery. Berlin: SpringerVerlag, 2006; 67-72.

9. Eavey D, Lubianca F. Canal wall window tympanomastoidectomy. Laryngoscope, 2000; 110(8): 1410-4.

10. Wilson H, David W. Titanium mesh for functional reconstruction of the mastoid cortex after mastoidectomy. Otol Neurotol, 2006; 27(1) 33-6.

11. Ezzat AEM, Eid MI. Evaluation of using Bioglass in obliteration of mastoid cavity. Curr Sci Int, 2014; 3(2): 87-94.

12. Roland P, Leach J. Reconstruction of the posterior ear canal. In: Haberman RS (ed.), Middle Ear and Mastoid Surgery. York, PA: Thieme Medical, 2004; 81-8.

13. Berrettini S, Ravecca F, de Vito A, Forli F, Valori S, Franceschini SS. Modified Bondy radical mastoidectomy: long-term personal experience, J Laryngol Otol, 2004; 118(5): 333-7.

14. Della Santina CC, Lee SC. Ceravital reconstruction of canal wall down mastoidectomy: long-term results. Arch Otolaryngol Head Neck Surg, 2006; 132(6): 617-23.

15. Visvanathan V, Kubba H, Morrissey C. Cholesteatoma surgery in children: 10-year retrospective review. J Laryngol Otol, 2012; 126(5): 450-3. 